\title{
Dissection of the metabolic actions of insulin in adipocytes from early growth-retarded male rats
}

\author{
S E Ozanne, C L Wang, M W Dorling and C J Petry
}

Department of Clinical Biochemistry, Addenbrooke's Hospital, Hills Road, Cambridge CB2 2QR, UK

(Requests for offprints should be addressed to S E Ozanne)

\begin{abstract}
Numerous studies have shown a relationship between early growth restriction and Type 2 diabetes. Studies have shown that offspring of rats fed a low protein (LP) diet during pregnancy and lactation have a worse glucose tolerance in late adult life compared with controls. In contrast, in young adult life LP offspring have a better glucose tolerance which is associated with increased insulin-stimulated glucose uptake into skeletal muscle. The aim of the present study was to compare the regulation of glucose uptake and lipolysis in adipocytes by insulin in control and LP offspring. LP adipocytes had increased basal and insulin-stimulated glucose uptake compared with controls. There was no difference in basal
\end{abstract}

rates of lipolysis. Isoproterenol stimulated lipolysis in both groups, but it was more effective on LP adipocytes. Insulin reduced lipolytic rates in controls to basal levels but had a reduced effect in LP adipocytes. Protein kinase B activity matched glucose uptake, with LP adipocytes having elevated activities. These results suggest that early growth retardation has long-term effects on adipocyte metabolism. In addition, they show selective resistance to different metabolic actions of insulin and provide insight into the mechanisms by which insulin regulates glucose uptake and lipolysis.

Journal of Endocrinology (1999) 162, 313-319

\section{Introduction}

A number of studies have shown that there is a relationship between poor early growth and the subsequent development of Type 2 diabetes mellitus in adulthood (Philips \& Hales 1996). A possible mechanism underlying this relationship is proposed in the 'thrifty phenotype hypothesis' (Hales \& Barker 1992). This suggests that during times of nutritional deprivation a growing foetus will undergo metabolic adaptations which are beneficial under conditions of poor postnatal nutrition. This so called 'programming' will therefore aid survival if the organism is born into conditions of limited nutrition. However, if the offspring are well or over-nourished then this may conflict with the earlier programming and Type 2 diabetes may occur.

A key feature of the thrifty phenotype hypothesis is the proposal that early growth retardation will lead to programmed changes in insulin sensitivity (insulin resistance being an important feature of Type 2 diabetes). This possibility has been investigated in a rat model of early growth retardation in which pregnant and lactating rats are fed either a control $(20 \%)$ or a low $(8 \%)$ protein (LP) diet (Dahri et al. 1991, Desai et al. 1996). Low protein offspring even when weaned onto a control (20\% protein) diet are permanently growth retarded (Desai et al. 1996). In late adult life the low protein offspring have a significantly worse glucose tolerance compared with control offspring (Hales et al. 1996). In contrast, at three months of age low protein offspring have a significantly better glucose tolerance than controls which is associated with increased glucose uptake into skeletal muscle (Ozanne et al. 1996) and adipocytes (Ozanne et al. 1997) in male offspring. In contrast, an in vivo study of female low protein offspring found no increased skeletal muscle glucose uptake (Holness 1996). Both skeletal muscle and adipocytes from male low protein offspring have increased levels of insulin receptors (Ozanne et al. 1996, 1997). Consistent with the elevated levels of insulin receptors, adipocytes from these low protein offspring also have increased basal and insulinstimulated levels of insulin receptor substrate-1 (IRS-1)associated phosphatidyl inositol (PI) 3-kinase activity (Ozanne et al. 1997). PI 3-kinase is a hetero-dimeric enzyme which consists of a regulatory and a catalytic subunit (reviewed by Shepherd et al. 1998). Activation of PI 3-kinase by interaction of the regulatory subunit with phosphorylated IRS-1 is required for insulin to stimulate glucose uptake. At least two insulin-regulated isoforms of the catalytic subunit exist in adipocytes; they are termed $\mathrm{p} 110 \alpha$ and $\mathrm{p} 110 \beta$ (Hiles et al. 1992, Hu et al. 1993). The precise role of these two subunits and the relative activity of each is not clear. However, it has been shown previously that adipocytes from low protein offspring have a 
striking reduction in the levels of the $\mathrm{p} 110 \beta$ catalytic subunit of phosphatidyl PI 3-kinase compared with controls (Ozanne et al. 1997).

In addition to stimulating glucose uptake via translocation of glucose transporter 4 (GLUT 4) vesicles to the plasma membrane, insulin has an array of other metabolic actions. In adipocytes one of the other main metabolic actions of insulin is to inhibit the breakdown of triglycerides into free fatty acids and glycerol. This anti-lipolytic action of insulin is thought to be mediated through inhibition either directly or indirectly of hormone sensitive lipase. The precise molecular actions leading to this inhibition are poorly defined but it is thought to occur, at least in part, through phosphorylation and activation of phosphodiesterase 3b (PDE 3b) (Degerman et al. 1997). Thus, the main aim of the present study was to compare the long-term effects of early growth retardation on the antilipolytic action of insulin and the ability of the hormone to regulate glucose uptake. These results were then related to protein kinase $\mathrm{B}(\mathrm{PKB})$ activity, a key enzyme downstream of PI 3-kinase in the insulin signalling cascade.

\section{Materials and Methods}

Analytical grade biochemicals were obtained from Sigma Chemical Co. or BDH Biochemicals (both of Poole, Dorset, UK), unless stated otherwise. Monocomponent porcine insulin was prepared from insulin zinc suspension B.B. (80 i.u./ml; Monotard, Novo Nordisk A/S, Bagsvaerd, Denmark) as outlined by Christensen et al. (1985). D-[U- $\left.{ }^{14} \mathrm{C}\right]$ glucose and $\left[{ }^{32} \mathrm{P}\right] \mathrm{ATP}$ were obtained from Amersham International, Amersham, Bucks, UK. Linco rat insulin radioimmunoassay kits were purchased from Biogenesis Ltd (Poole, Dorset, UK).

\section{Animals}

All procedures involving animals were conducted under the British Home Office Animals Act 1986. Virgin female Wistar rats (initial weight $240-260 \mathrm{~g}$ ) used for the study were housed individually and were maintained at $22{ }^{\circ} \mathrm{C}$ on a $12 \mathrm{~h}$ light/12 $\mathrm{h}$ dark cycle. They were mated and day 0 of gestation was taken as the day on which vaginal plugs were expelled. The rats were fed a diet containing $20 \%$ protein or an isocalorific diet containing $8 \%$ protein (LP) throughout pregnancy and lactation. The composition and source of the diets was as described by Snoeck et al. (1990). It should be noted that as the diets are isocalorific, the decrease in protein is substituted with carbohydrate. Hence the diet could be described as a low protein/high carbohydrate diet and any effects observed may result from either the low protein, the elevated carbohydrate or a combination of the two.
Spontaneous delivery took place on day 22 of pregnancy after which at 3 days of age litters were reduced randomly to 8 pups, thus ensuring a standard litter size per mother. At 21 days of age all pups were weaned onto a $20 \%$ protein diet. For simplicity the two groups of offspring are termed 'control' and 'low protein', however it is emphasised that only the mothers undergo dietary manipulation. All rats studied were three-month-old males and were starved overnight prior to commencement of procedures.

\section{Adipocyte isolation}

Adipocytes were isolated from epididymal fat pads by collagenase $(1 \mathrm{mg} / \mathrm{ml})$ digestion as described previously (Cushman 1970). Following isolation, adipocytes were washed twice with Krebs-Ringer-Hepes $(30 \mathrm{mM})$ buffer ( $\mathrm{pH} 7 \cdot 4$ ) containing $2 \cdot 5 \%$ bovine serum albumin (BSA) (fraction V). For PKB expression analysis, cells were washed 3 times in BSA-free Krebs-Ringer-Hepes

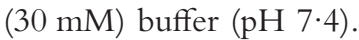

\section{Glucose uptake studies}

Cells $\left(12 \%\right.$ suspension) were incubated at $37^{\circ} \mathrm{C}$ with constant shaking in an $8 \%$ suspension by volume, in Krebs-Ringer-Hepes (30 mM) buffer ( $\mathrm{pH} 7 \cdot 4)$ with $2 \cdot 5 \%$ BSA (fraction V), $200 \mathrm{nM}$ adenosine either without (basal) or with (insulin-stimulated) $80 \mathrm{nM}$ insulin. Following an initial 30-min incubation period with or without insulin, $\left[\mathrm{U}_{-}{ }^{14} \mathrm{C}\right]$ glucose $(3 \mu \mathrm{M})$ was added for $60 \mathrm{~min}$ and the reaction was terminated by separating cells from media by spinning the suspension through dinonyl phthalate oil (Shepherd et al. 1993).

\section{Lipolysis studies}

Cells $\left(12 \%\right.$ suspension) were incubated at $22{ }^{\circ} \mathrm{C}$ in an $8 \%$ suspension by volume, in Krebs-Ringer-Hepes $(30 \mathrm{mM})$ buffer ( $\mathrm{pH} 7 \cdot 4$ ) with $2.5 \%$ BSA (fraction V). In the dose-response studies $0-1.6 \mu \mathrm{M}$ isoproterenol was included. For the anti-lipolytic experiments adipocytes were incubated either without additions (basal) or with $0 \cdot 1 \mu \mathrm{M}$ isoproterenol (stimulated) containing either 0,1 , 10 or $100 \mathrm{nM}$ insulin. After $1 \mathrm{~h}$ media were removed and glycerol release was measured using a kit purchased from Sigma Chemical Co.

\section{$P K B$ assay}

Cells were incubated for $5 \mathrm{~min}$ at $37^{\circ} \mathrm{C}$ in Krebs-RingerHepes in the absence or presence of $100 \mathrm{nM}$ insulin. Reactions were stopped by the addition of $27 \mu \mathrm{l}$ stop solution (74 mM EDTA, $37 \mathrm{mM}$ EGTA, $0.037 \mathrm{mM}$ microcystin, $3 \cdot 7 \% 2$-mercaptoethanol and $37 \mathrm{mM}$ sodium orthovanadate) and then snap-frozen in liquid nitrogen and stored at $-80{ }^{\circ} \mathrm{C}$ prior to analysis. Protein kinase B 
activity was determined as described previously (Walker et al. 1998). In brief, samples were thawed, centrifuged at $20000 \times \boldsymbol{g}$ for $5 \mathrm{~min}$ and the infranatant collected. PKB $\beta$ and PKB $\alpha$ were immunoprecipitated as descibed (Walker et al. 1998) and assayed for PKB activity using Crosstide (Cross et al. 1995).

\section{Western blot analysis of PKB expression}

$\mathrm{PKB} \alpha$ and $\mathrm{PKB} \beta$ expression were determined by Western blot analysis as described previously (Walker et al. 1998). Blots were scanned and quantified using the NIH Image Analyser program.

\section{Protein and insulin assay}

Protein content was determined in 12\% adipocyte suspensions in Krebs-Ringer-Hepes without BSA by a modification of the Lowry method (Schacterle \& Pollack 1973). Plasma insulin was measured by radioimmunoassay according to the manufacturer's protocol (Biogenesis).

\section{Statistical analyses}

All statistical calculations were carried out using Statworks statistical software (Cricket Software Computer Associates, Slough, Berkshire, UK). For all data sets it was first determined that the data were normally distributed and where comparisons were to be made, that there was no significant difference in the variances of the two groups. These conditions were met in all cases and the significance of any difference between groups was examined by the Students $t$-test. Results in all cases are given as means \pm S.E.M., together with the absolute probability $(P)$ value where appropriate.

\section{Results}

\section{Basic animal data}

Low protein offspring had significantly lower body weights compared with controls $(501 \pm 13 \mathrm{~g}$ compared with $398 \pm 13 \mathrm{~g}, P<0 \cdot 001)$. In addition epididymal fat pads were reduced in weight $(9 \cdot 7 \pm 0.9 \mathrm{~g}$ compared with $4 \cdot 5 \pm 0.4 \mathrm{~g}, P<0 \cdot 001)$. There was no difference in fasting plasma glucose levels $(5 \cdot 2 \pm 0 \cdot 2 \mathrm{mM}$ in controls and $5 \cdot 2 \pm 0 \cdot 1 \mathrm{mM}$ in low protein offspring). In addition fasting plasma insulin levels were similar in the two groups $(310 \pm 51 \mathrm{pM}$ in controls and $293 \pm 54 \mathrm{pM}$ in low protein offspring).

\section{Glucose uptake}

Adipocytes from low protein offspring had a significantly $(P<0 \cdot 01)$ higher basal glucose uptake compared with

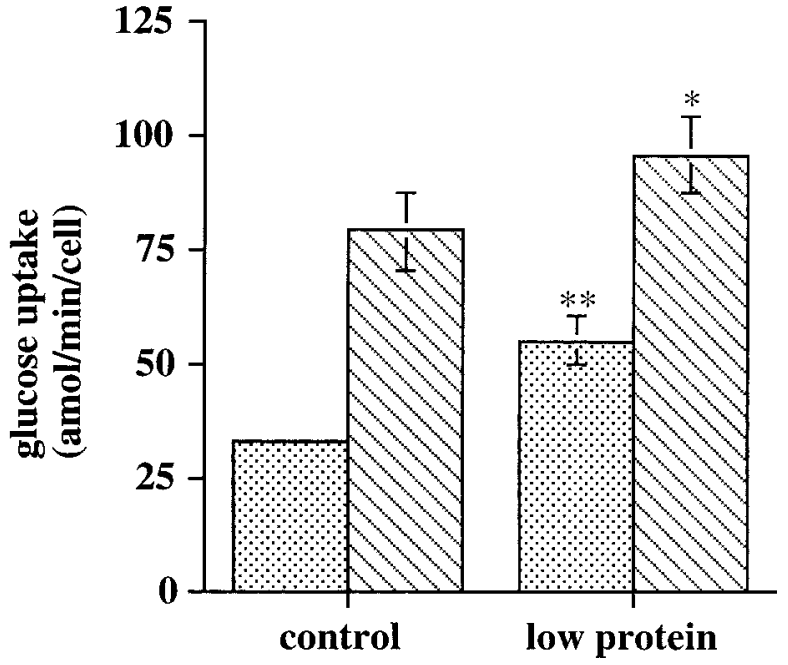

Figure 1 The effect of insulin on glucose uptake into freshly isolated adipocytes. Adipocytes were incubated with a modified Krebs-Ringer buffer in the absence (basal, stippled bars) or presence (hatched bars) of insulin $(80 \mathrm{nM})$ before addition of $\left[\mathrm{U}-{ }^{14} \mathrm{C}\right]$ glucose. Glucose uptake was then determined by liquid scintillation counting as described in the Materials and Methods section. Results are expressed as means \pm S.E.M. of 6 separate sets of control and low protein experiments, each performed in triplicate. ${ }^{*} P<0 \cdot 05,{ }^{*} P<0 \cdot 01$ compared with controls.

controls (Fig. 1). In addition they had a significantly $(P<0.05)$ elevated insulin-stimulated glucose uptake compared with controls (Fig. 1).

\section{Lipolysis}

Basal rates of lipolysis were similar in control and LP adipocytes (Fig. 2 and Table 1). The dose-response data show that isoproterenol stimulated $(P<0 \cdot 001)$ lipolysis in both groups; however it had a significantly greater effect on LP adipocytes at every concentration tested (Table 1). Insulin (at maximal concentrations) reduced $(P<0 \cdot 001)$ lipolytic rates (from a submaximal level) in controls to basal levels but had a markedly reduced effect in LP adipocytes $(P<0 \cdot 001$ compared with control) (Fig. 2). A submaximal concentration of insulin reduced glycerol release from control adipocytes $(P<0 \cdot 01)$ but had no effect on the low protein group (Fig. 2).

\section{PKB activity}

Adipocytes from low protein offspring had a significantly $(P<0 \cdot 05)$ higher basal PKB $\beta$ activity compared with controls (Fig. $3 a$ ). In both groups insulin stimulated PKB $\beta$ activity. Low protein offspring adipocytes tended $(P=0 \cdot 10)$ to have a higher insulin-stimulated PKB $\beta$ activity compared with controls; however this did not reach statistical significance in the number of animals studied. $\mathrm{PKB} \alpha$ activity was also detected in adipocyte extracts from 


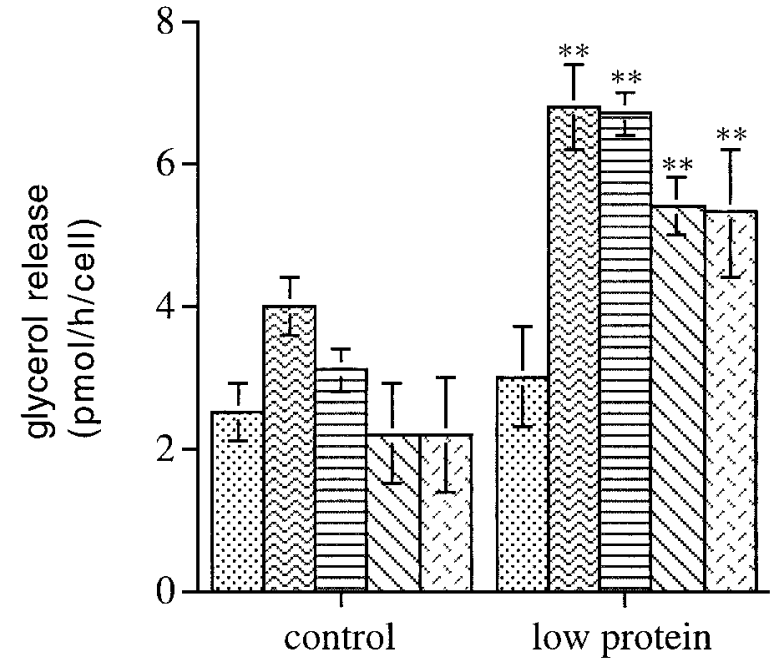

Figure 2 The effect of isoproterenol and insulin on lipolysis in freshly isolated adipocytes. Adipocytes were incubated with a modified Krebs-Ringer buffer in the absence or presence of isoproterenol $(0 \cdot 1 \mu \mathrm{M})$ and insulin $(1 \mathrm{nM}, 10 \mathrm{nM}$ or $100 \mathrm{nM})$. Glycerol release was measured as described in the Materials and Methods section. Results are expressed as means \pm S.E.M. of 5 separate sets of control and low protein experiments, each performed in triplicate. In each group the 5 bars are arranged in the following order: (1) basal, (2) isoproterenol stimulated, (3) + $1 \mathrm{nM}$ insulin, (4) + $10 \mathrm{nM}$ insulin, (5) +100 nM insulin. ${ }^{* *} P<0 \cdot 01$ compared with controls.

both experimental groups (Fig. 3b). Insulin had a small stimulatory effect $(P<0 \cdot 01)$ on $\mathrm{PKB} \alpha$ activity in control adipocytes but had no statistically significant effect in the low protein group (Fig. 3b).

\section{PKB expression}

There were no detectable differences in PKB $\alpha(189 \pm 6$ arbitrary units for controls and $178 \pm 9$ arbitrary units for low protein group) (Fig. 4a) or PKB $\beta$ (206 \pm 10 arbitrary units for controls and $198 \pm 9$ arbitrary units for low

Table 1 Dose-response of isoproterenol-stimulated glycerol release

Glycerol release (pmol/h/cell)

\begin{tabular}{|c|c|c|}
\hline \multirow{3}{*}{ Isoproterenol $(\mu \mathrm{M})$} & \\
\hline & Control & Low protein \\
\hline & & \\
\hline 0 & $2 \cdot 3 \pm 0 \cdot 2$ & $2 \cdot 6 \pm 0 \cdot 2$ \\
\hline 0.05 & $2 \cdot 7 \pm 0 \cdot 2$ & $3 \cdot 8 \pm 0 \cdot 2^{* *}$ \\
\hline $0 \cdot 1$ & $4 \cdot 7 \pm 0 \cdot 3$ & $7 \cdot 8 \pm 0 \cdot 2^{* * *}$ \\
\hline $0 \cdot 2$ & $9 \cdot 5 \pm 0 \cdot 6$ & $17 \cdot 6 \pm 1 \cdot 1^{* * *}$ \\
\hline $0 \cdot 4$ & $13 \cdot 0 \pm 1 \cdot 2$ & $25 \cdot 5 \pm 1 \cdot 8^{* * *}$ \\
\hline $0 \cdot 8$ & $14 \cdot 6 \pm 1 \cdot 5$ & $37 \cdot 0 \pm 2 \cdot 6^{* * *}$ \\
\hline $1 \cdot 6$ & $14 \cdot 9 \pm 1 \cdot 7$ & $35 \cdot 6 \pm 5 \cdot 7^{* *}$ \\
\hline
\end{tabular}

${ }^{* *} P<0 \cdot 01,{ }^{* * *} P<0 \cdot 001$ compared with controls. protein group) (Fig. 4b) expression between experimental groups.

\section{Discussion}

The present study was designed to address the possibility that early growth retardation could have a number of effects on the metabolic actions of insulin on adipocytes. Consistent with previous findings, adipocytes from maternally malnourished rats had increased basal and insulin-stimulated glucose uptakes. This enhanced glucose uptake is associated with increased insulin receptors and IRS-1-associated PI 3-kinase activity (Ozanne et al. 1997).

Isoproterenol (a synthetic catecholamine) stimulated lipolysis in both control and low protein adipocytes. However, it had a greater stimulatory effect in the low protein group. This suggests that low protein adipocytes are more sensitive to catecholamines. At present the molecular basis of this apparent enhanced sensitivity is unclear. It is possible that, like insulin receptors, there are increased levels of adrenergic receptors on adipocyte membranes from low protein offspring. It is noteworthy that a similar increased response to catecholamines is observed in adipocytes isolated from pregnant rats who are currently being fed a low protein diet (Holness et al. 1998).

In contrast to the enhanced sensitivity of low protein adipocytes to insulin's ability to stimulate glucose uptake, these adipocytes had an apparent resistance to the antilipolytic action of insulin. This finding is surprising in light of the findings that low protein adipocytes have elevated levels of insulin receptors and parallel increases in basal and insulin-stimulated IRS-1-associated PI 3-kinase activity (Ozanne et al. 1997). It has been shown previously that the anti-lipolytic action of insulin is sensitive to wortmannin, a potent inhibitor of PI 3-kinase (Okada et al. 1994). This would suggest that PI 3-kinase is necessary for the antilipolytic action of insulin. However, the current data suggest PI 3-kinase activity alone is not sufficient to mediate the anti-lipolytic action of insulin.

There are a number of possible explanations for the current findings. First, the isoform of the catalytic subunit of PI 3-kinase which is activated may be important. The low protein adipocytes have relatively low levels of $\mathrm{p} 110 \beta$ compared with controls but have similar levels of $\mathrm{p} 110 \alpha$ (Ozanne et al. 1997). Thus, in low protein adipocytes most catalytic activity will be that of $\mathrm{p} 110 \alpha$. One possibility is, therefore, that activation of $\mathrm{p} 110 \alpha$ is necessary for the stimulation of glucose uptake by insulin; indeed over-expression of $\mathrm{p} 110 \alpha$ has been shown to enhance glucose uptake into 3T3-L1 adipocytes (Katagiri et al. 1996). In contrast, p110 $\beta$ activation may be required for the anti-lipolytic action of insulin. It is difficult, at first, to see how, given that their products are identical, the two isoforms could regulate distinct pathways. It is possible that they differ in their subcellular location. There is evidence 

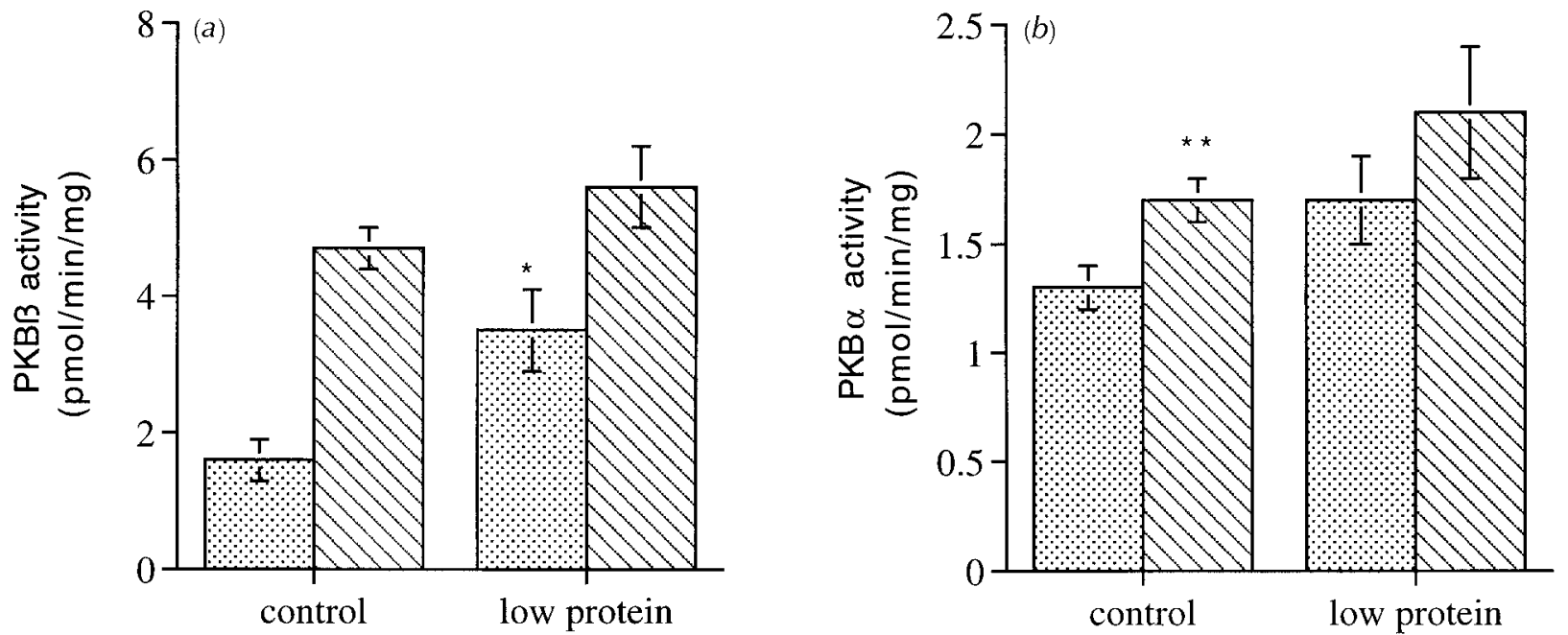

Figure 3 The effect of insulin on (a) PKB $\beta$ and (b) PKB $\alpha$ activity in adipocytes. Adipocytes were incubated with a modified Krebs-Ringer buffer in the absence (basal, stippled bars) or presence of insulin (100 nM) (hatched bars). PKB activity was then measured in immunoprecipitates as described in the Materials and Methods section. Results are expressed as means \pm S.E.M. of 6 separate sets of control and low protein experiments, each performed in duplicate. ${ }^{*} P<0 \cdot 05$ compared with controls; ${ }^{* *} P<0 \cdot 01$ compared with the basal state.

that PI 3-kinase activity can be differentially increased in different subcellular locations which provides a mechanism by which different hormones could activate PI 3-kinase signalling cascades and achieve different signalling outcomes (Nave et al. 1996). Both insulin and platelet-derived growth factor (PDGF) activate PI 3-kinase activity in 3T3-L1 adipocytes (Nave et al. 1996). However, insulin stimulates glucose transport into these cells whereas PDGF has no effect on glucose transport. Treatment of 3T3-L1 adipocytes with insulin has been shown to activate PI 3-kinase activity in a microsomal membrane fraction whereas treatment of these cells with PDGF activates PI 3-kinase activity in the plasma membrane fraction (Nave et al. 1996). Interestingly, it has also been shown recently (Kurosu et al. 1997) that a PI 3-kinase consisting of $\mathrm{p} 110 \beta$ (catalytic subunit) and p85 (regulatory subunit) can be activated by the $\beta \gamma$ subunits of a G-protein as well as by a phosphopeptide.

(a) CONTROL

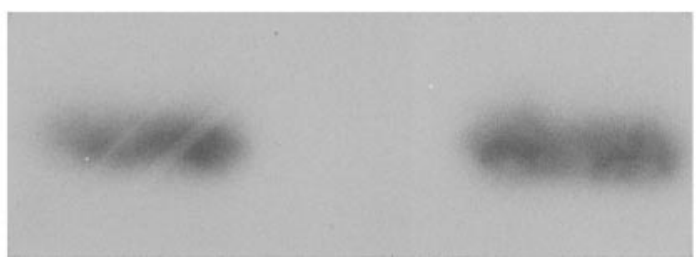

No such activation by $\beta \gamma$ was observed in a PI 3-kinase consisting of $p 110 \alpha$ and $p 85$. This suggests that $p 110 \beta /$ p85 PI 3-kinase has the potential to be regulated in a cooperative manner by insulin and hormones, such as catecholamines, which act via G-protein-linked receptors.

There are other possible mechanisms by which this divergence of insulin signalling pathways occurs. There may be altered levels of expression of components of the insulin signalling pathway downstream of PI 3-kinase which are necessary for the antilipolytic action of insulin but which are not required for insulin to stimulate glucose transport. Protein kinase B is one key enzyme downstream of PI 3-kinase which is thought to mediate a number of actions of insulin including the stimulation of cardiac muscle glycolysis via 6-phosphofructo-2-kinase (Deprez et al. 1997), the stimulation of glycogen synthesis via inhibition of glucogen synthase kinase 3 (Cohen et al. (b) CONTROL

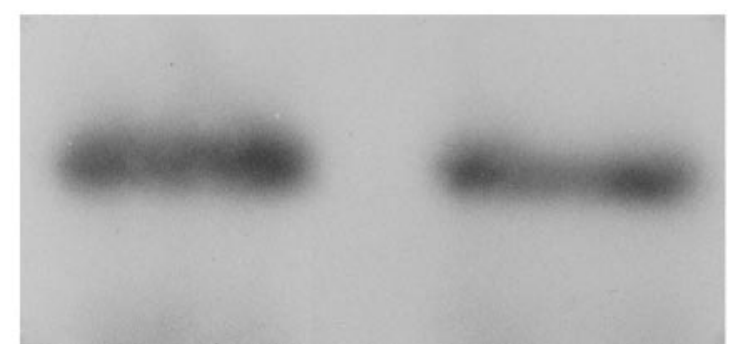

Figure 4 Immunoblot analysis of $\mathrm{PKB} \alpha(a)$ and $\mathrm{PKB} \beta(b)$ expression in adipocytes. Lysates (25 $\mu \mathrm{g})$ were electrophoresed and transferred to nitrocellulose paper, which was reacted with either anti-PKB $\alpha$ (a) or anti-PKB $\beta$ (b) antibody. Similar results were observed on 6 separate occasions. 
1997) and the stimulation of glucose uptake into adipocytes (Kohn et al. 1996) and L6 myotubes (Hajduch et al. 1998). PI 3-kinase activity is thought to be required for PKB activation as such activation can be prevented by inhibitors of PI 3-kinase and by overexpression of dominant negative forms of PI 3-kinases (reviewed by Alessi \& Cohen 1998). Little data is available on the involvement of PKB in mediating the anti-lipolytic action of insulin. There is a report (Wijkander et al. 1998) which suggests that in rat adipocytes the kinase that phosphorylates and thereby activates phosphodiesterase $3 \mathrm{~b}$ (PDE $3 \mathrm{~b}$ ) co-elutes with $\mathrm{PKB}$. The data from the present study suggest that PKB activation is not sufficient for the anti-lipolytic action of insulin. Both low protein and control adipocytes contained PKB $\alpha$ and PKB $\beta$ activity. PKB $\beta$ activity increased in both experimental groups on stimulation by insulin. However, the adipocytes from low protein offspring had a significantly higher basal activity and tended to have a higher insulin-stimulated activity compared with controls. This pattern of activity is similar to that seen with glucose uptake and that seen previously for IRS-1-associated PI 3-kinase activity. This alteration in PKB activity was not related to any changes in expression of $\mathrm{PKB}$ protein. These findings are consistent with PKB activation being a downstream response to PI 3-kinase activation. In contrast, minimal stimulation of $\mathrm{PKB} \alpha$ in the presence of insulin was observed in both experimental groups. This is consistent with $\mathrm{PKB} \beta$ being the key insulin-sensitive form of the enzyme in adipocytes (Walker et al. 1998). A possible explanation for a reduction in the anti-lipolytic action of insulin despite PKB activation is that there is something specific to the activation of PKB by the $\mathrm{p} 110 \beta$ isoform of the catalytic subunit of PI 3-kinase that is required for the anti-lipolytic action of insulin.

There are other examples of differential changes in sensitivity to various actions of insulin. In the condition pseudoacromegaly, resistance to the metabolic actions of insulin (for example glycogen synthase activation) are observed; however these patients are still sensitive to the mitogenic actions of insulin (Flier et al. 1993). An example of selective resistance to different metabolic actions of insulin can be seen in people with essential hypertension. A reduction in the ability of physiological insulin concentrations to stimulate whole body glucose uptake is observed. However, a number of other actions of insulin (e.g. suppression of hepatic glucose output, lipolysis and lipid oxidation) are unaffected (Ferrannini et al. 1990). Likewise, adipocytes isolated from Dahl rats (which are genetically hypertensive) have been reported to have lower levels of maximal insulin-stimulated glucose transport but similar responsiveness to the anti-lipolytic action of insulin (Reaven et al. 1991). In addition, in patients with insulin-dependent diabetes mellitus, decreased levels of glucose uptake during exercise have been observed while rates of lipolysis remained comparable to controls (Raguso et al. 1995).
These results demonstrate that early growth retardation is associated with long-term changes in adipocyte metabolism. These adipocytes provide a useful model for studying mechanisms by which insulin signalling pathways diverge and help in the understanding of the molecular machinery involved in the regulation of glucose uptake and lipolysis by insulin.

\section{Acknowledgements}

We thank D Hutt, A Flack, A Wayman and L Smith of the Dunn Nutrition Laboratory Animal Unit for their invaluable assistance. We are grateful to Professor C N Hales, Professor K Siddle and Professor Sir P Cohen for advice and useful discussions. We also thank Dr D Alessi for help with and providing reagents for the protein kinase $\mathrm{B}$ assays and many useful discussions. This work was supported by the British Diabetic Association, the Medical Research Council, the Parthenon Trust and the Wellcome Trust.

\section{References}

Alessi DR \& Cohen P 1998 Mechanism of activation and function of protein kinase B. Current Opinion in Genetics and Development $\mathbf{8}$ 155-162.

Christensen JR, Smith GD \& Peters TJ 1985 Characterization of insulin uptake into subcellular fractions of perfused rat liver using two different iodinated tracers. Cell Biochemistry and Function 3 13-19.

Cohen P, Alessi DR \& Cross DAE 1997 PDK1, the missing link in insulin signal transduction. FEBS Letters 410 3-10.

Cross DAE, Alessi DR, Cohen P, Andjelkovic M \& Hemmings BA 1995 Inhibition of glycogen-synthase kinase-3 by insulin mediated by protein-kinase-B. Nature 378 785-789.

Cushman SW 1970 Structure-function relationships in the adipose cell. 1. Ultrastructure of the isolated adipose cell. Journal of Cell Biology 46 326-341.

Dahri S, Snoeck A, Reusens-Billen B, Remacle C \& Hoet JJ 1991 Islet function in offspring of mothers on low-protein diet during gestation. Diabetes 40 115-120.

Degerman E, Belfrage P \& Manganiello V 1997 Structure, localization and regulation of cGMP-inhibited phosphodiesterase (PDE3). Journal of Biological Chemistry 272 6823-6826.

Deprez J, Vertommen D, Alessi DR, Hue L \& Rider MH 1997 Phosphorylation and activation of heart 6-phosphofructo-2-kinase by protein kinase-B and other protein kinases of the insulin signalling cascades. Journal of Biological Chemistry $27217268-17275$.

Desai M, Crowther NJ, Lucas A \& Hales CN 1996 Organ-selective growth in the offspring of protein restricted mothers. British Journal of Nutrition 76 591-603.

Ferrannini E, Haffner SM \& Stern MP 1990 Essential hypertension: an insulin-resistant state. Journal of Cardiovascular Pharmacology 15 (Suppl 5) S18-S15.

Flier JS, Moller DE, Moses AC, O'Rahilly S, Chaiken RL, Grigorescu F, Elahi D, Kahn BB, Weinreb JE \& Eastman R 1993 Insulin mediated pseudoacromegaly: clinical and biochemical characterization of a syndrome of selective insulin resistance. Journal of Clinical Endocrinology and Metabolism 76 1533-1541.

Hajduch E, Alessi DR, Hemmings BA \& Hundal H 1998 Protein kinase $\mathrm{B}$ mediates the insulin induced increase in glucose and amino acid uptake in L6 myotubes. Diabetes 47 1006-1013. 
Hales CN \& Barker DJP 1992 Type 2 (non-insulin-dependent) diabetes mellitus: the thrifty phenotype hypothesis. Diabetologia 35 595-601.

Hales CN, Desai M, Ozanne SE \& Crowther NJ 1996. Fishing in the stream of diabetes: from measuring insulin to the control of fetal organogenesis. Biochemical Society Transactions 24 341-350.

Hiles ID, Otsu M, Volinia S, Fry MJ, Gout I, Dhand R, Panayotou G, Ruiz-Larrea Thompson FA, Totty N, Hsuan JJ, Courtneidge SA, Parker PJ \& Waterfield MD 1992 Phosphatidylinositol 3-kinase: structure and expression of the $110 \mathrm{kD}$ catalytic subunit. Cell 70 419-429.

Holness MJ 1996 Impact of early growth retardation on glucoregulatory control and insulin action in mature rats. American Journal of Physiology 270 E946-E954.

Holness MJ, Fryer LG, Priestman DA \& Sugden MC 1998 Moderate protein restriction during pregnancy modifies the regulation of triacylglycerol turnover and leads to dysregulation of insulin's anti-lipolytic action. Molecular and Cellular Endocrinology 142 25-33.

Hu P, Mondino A, Skolnik EY \& Schlessinger J 1993 Cloning of a novel, ubiquitously expressed human phosphatidyl inositol 3-kinase and identification of binding site to p85. Molecular and Cellular Biology 13 7677-7688.

Katagiri H, Asano T, Ishihara, Inukai K, Shibasaki Y, Kikuchi M, Yazaki Y \& Oka Y 1996 Overexpression of catalytic subunit p110 $\alpha$ of phosphatidylinositol 3-kinase increases glucose transport activity with translocation of glucose transporters in 3T3-L1 adipocytes. Journal of Biological Chemistry 271 16987-16990.

Kohn AD, Summers SA, Birnbaum MJ \& Roth RA 1996 Expression of a constitutively active Akt Ser/Thr kinase in 3T3-L1 adipocytes stimulates glucose-uptake and glucose-transporter-4 translocation. Journal of Biological Chemistry 271 31372-31378.

Kurosu H, Maehama T, Okada T, Yamamoto T, Hoshino S, Fukui Y, Ui M, Hazeki O \& Katada T 1997 Heterodimeric phosphoinositide 3-kinase consisting of $\mathrm{p} 85$ and $\mathrm{p} 110 \beta$ is synergistically activated by the $\beta \gamma$ subunits of $G$ proteins and phosphotyrosol peptide. Journal of Biological Chemistry 272 24252-24256.

Nave BT, Haigh RJ, Hayward AC, Siddle K \& Shepherd PR 1996 Compartment-specific regulation of phosphoinositide 3-kinase by platelet-derived growth factor and insulin in 3T3-L1 adipocytes. Biochemical Journal 318 55-60.

Okada T, Kawano Y, Sakakibara T, Hazeki O \& Ui M 1994 Essential role of phosphatidyl inositol 3-kinase in insulin-induced glucose transport and antilipolysis in rat adipocytes. Studies with a selective inhibitor wortmannin. Journal of Biological Chemistry 269 3568-3573
Ozanne SE, Wang CL, Coleman N \& Smith GD 1996. Altered muscle insulin sensitivity in the male offspring of protein malnourished rats. American Journal of Physiology 271 E1128-E1134.

Ozanne SE, Nave BT, Wang CL, Shepherd PR, Prins J \& Smith GD 1997 Poor fetal nutrition causes long-term changes in expression of insulin signalling components in adipocytes. American Journal of Physiology 273 E46-E51.

Philips DIW \& Hales CN 1996 The intrauterine environment and susceptibility to non-insulin dependent diabetes and the insulin resistance syndrome. In The Diabetes Annual, vol 10, pp 1-13. Eds SM Marshall, PD Home \& RA Rizza. Amsterdam: Elsevier.

Raguso CA, Coggan AR, Gastaldelli A, Sidossis LS, Bastyr III EJ \& Wolfe RR 1995 Lipid and carbohydrate metabolism in IDDM during moderate and intense exercise. Diabetes 44 1066-1074.

Reaven GM, Twersky J \& Chang H 1991 Abnormalities of carbohydrate and lipid metabolism in Dahl rats. Hypertension 18 630-635.

Schacterle GR \& Pollack RL 1973 A simplified method for the quantitative assay of small amounts of proteins in biologic material. Analytical Biochemistry 51 654-655.

Shepherd PR, Gnudi L, Tozzo E, Yang H, Leach F \& Kahn BB 1993 Adipose cell hyperplasia and enhanced glucose disposal in transgenic mice overexpressing GLUT 4 selectively in adipose tissue. Journal of Biological Chemistry 268 22243-22246.

Shepherd PR, Withers DJ \& Siddle K 1998 Phosphoinositide 3-kinase: the key switch mechanism in insulin signalling. Biochemical Journal 333 471-490.

Snoeck I, Remacle C, Reusens B \& Hoet JJ 1990 Effect of a low protein diet during pregnancy on the fetal rat endocrine pancreas. Biology of the Neonate 57 107-118.

Walker KS, Deak M, Paterson A, Hudson K, Cohen P \& Alessi DR 1998 Activation of protein kinase $\mathrm{B} \beta$ and $\gamma$ isoforms in vivo and by 3 -phosphoinositide-dependent protein kinase-1 in vitro: comparison with protein kinase B $\alpha$. Biochemical Journal 331 299-308.

Wijkander J, Landstrom TR, Manganiello V, Belfrage P \& Degerman E 1998 Insulin-induced phosphorylation and activation of phosphodiesterase $3 \mathrm{~B}$ in rat adipocytes: possible role for protein kinase $\mathrm{B}$ but not mitogen-activated protein kinase or p70 S6 kinase. Endocrinology $139219-227$.

Received 13 November 1998

Revised manuscript received 24 March 1999 Accepted 9 April 1999 